\title{
Diversity of Norwegian sea slugs (Nudibranchia): new species to Norwegian coastal waters and new data on distribution of rare species
}

\author{
Jussi Evertsen' and Torkild Bakken'
}

\begin{abstract}
Evertsen J, Bakken T. 2013. Diversity of Norwegian sea slugs (Nudibranchia): new species to Norwegian coastal waters and new data on distribution of rare species. Fauna norvegica 32: 45-52.

A total of 5 nudibranch species are reported from the Norwegian coast for the first time (Doridoxa ingolfiana, Goniodoris castanea, Onchidoris sparsa, Eubranchus rupium and Proctonotus mucroniferus). In addition 10 species that can be considered rare in Norwegian waters are presented with new information (Lophodoris danielsseni, Onchidoris depressa, Palio nothus, Tritonia griegi, Tritonia lineata, Hero formosa, Janolus cristatus, Cumanotus beaumonti, Berghia norvegica and Calma glaucoides), in some cases with considerable changes to their distribution. These new results present an update to our previous extensive investigation of the nudibranch fauna of the Norwegian coast from 2005, which now totals 87 species. An increase in several new species to the Norwegian fauna and new records of rare species, some with considerable updates, in relatively few years results mainly from sampling effort and contributions by specialists on samples from poorly sampled areas.
\end{abstract}

doi: 10.5324/fn.v31i0.1576. Received: 2012-12-02. Accepted: 2012-12-20.

Published on paper and online: 2013-02-13.

Keywords: Nudibranchia, Gastropoda, taxonomy, biogeography

1. Museum of Natural History and Archaeology, Norwegian University of Science and Technology, NO-7491 Trondheim, Norway

Corresponding author: Jussi Evertsen

E-mail: jussi.evertsen@ntnu.no

\section{INTRODUCTION}

Sea slugs are a group of gastropods that are challenging to identify from preserved specimens. Due to this, knowledge of this group in Norwegian waters has been fragmentary with the last published account in 1942. In 1997 we started a project to map which species are actually present in Norwegian waters. An exhaustive list was published (Evertsen \& Bakken 2005) presenting 82 nudibranch species from the Norwegian coast. This work also clarified older incorrect literature references reporting species from Norwegian waters, but since some original references did not document actual records, some previously recorded species were not included in the list of 82 species.

The project on Norwegian nudibranchs has continued. From 2007 the project has continued with an aim of obtaining ethanol fixed specimens for as many species of Norwegian nudibranchs as possible. To do molecular work to solve taxonomic problems and to cover the nudibranch fauna with DNA barcodes has been the main aims. These aims have increased sampling especially through extensive fieldwork and cooperation with enthusiastic SCUBA divers and underwater photographers. This effort has revealed several new records of nudibranch species not previously recorded for Norwegian coastal waters, as well as new records of species with poorly known distributions.

Sampling effort has been aimed at specific localities in order to obtain as many species as possible. Especially extensive fieldwork in the Sognefjorden at Gulen where the project over the last four years contributed to workshops educating divers and underwater photographers interested in marine biology, has added valuable observations to the accumulated knowledge of the nudibranch fauna.

Work on taxonomy of groups of species and a broad DNA barcoding approach of Norwegian nudibranchs has a focus in the project "Nudibranchs in Norwegian waters". These aspects will in the time ahead cover several groups of species that are 
challenging taxonomically, in order to further clarify species diversity and abundance. The aim of this paper is therefore solely to document new species for Norwegian waters and updates on distribution for species which have been considered rare.

\section{MATERIAL AND METHODS}

Scuba-diving has been the primary method of collecting nudibranchs, but specimens have also been obtained from dredging (Table 1). By the help of skilled underwater photographers species have been documented in situ. Only specimens needed for documentation and molecular studies have been preserved. Collected specimens have been fixed and preserved in 96\% ethanol. Specimens, and vouchers for DNA barcoding, are deposited in the collections at the Norwegian University of Science and Technology, Museum of Natural History and Archaeology (NTNU-VM), and the University Museum in Bergen, University of Bergen (ZMBN).

Different localities have been visited several times while single finds has also contributed to new records. Specifically the locality Glossvika in Gulen (Table 1) near the mouth of the Sognefjord has been especially interesting, with a range of different habitats within swimming distance from the pier. Divers have easily brought back live specimens for study in a field laboratory. From this locality alone we have over 3 years observed in total more than 50 species.

\section{RESULIS}

A total of 5 species are reported as new to Norwegian waters. For 10 species new data has added considerably to the knowledge of their distribution and abundance. Totally there are currently 87 species of Nudibranchia known from Norwegian waters (Appendix 1).

In the materials examined section for each species below, material deposited in the collections is given by their registration number. Material reported earlier (Evertsen \& Bakken 2002, 2005) has not been included.

\section{Doridoxa ingolfiana Bergh, 1899}

Doridoxa ingolfiana.- Bergh 1899: 15-19, pl. 2, figs 3-15, pl. 3, figs 1-3, pl. 5, figs 29-30.- Just \& Edmunds: 44, pl. 18A-D.

Material examined: ZMBN 89714 (1), MAREANO stn R189349. ZMBN 89713 (1), MAREANO stn R108-335.

Remarks: Worldwide only four specimens have previously been reported: from Iceland (Bergh 1899, 1900, 2 specimens), west and south of Greenland (Bergh 1899, 1900; Lemche 1941, 1 specimen), and north of the Faroe Islands (Sneli et al. 2005, 1 specimen), with a bathymetrical range from $103 \mathrm{~m}$ to $900 \mathrm{~m}$ depth. The MAREANO samples therefore represent the first record of this species along the coast of Norway, where two

Table 1.List of stations giving locality data where nudibranch species were found in recent sampling.

\begin{tabular}{lllllll}
\hline Date & Station \# & Locality & Latitude & Longitude & Depth $(\mathrm{m})$ & Gear \\
\hline 5 Nov 2007 & 2007007 & Tørrisholmflua, Bjugn & 63,79121667 & 9,486333 & $37-50$ & Triangular dredge \\
22 March 2008 & 2008003 & Ellingøyan, Mausund, Frøya & 63.8918667 & 8.60351667 & $5-20$ & SCUBA \\
23 March 2008 & 2008004 & Bukkholman, Mausund, Frøya & 63.87981667 & 8.6222 & $5-15$ & SCUBA \\
18 April 2009 & 2009009 & Agdenes, Trondheimsfjord & 63.6125667 & 9.74385 & $2-30$ & SCUBA \\
8 May 2009 & 2009012 & Røberg, Trondheimsfjord & 63.4743 & 10.0031 & $180-200$ & Triangular dredge \\
30 Sept 2009 & 2009024 & Nord-Leksa, Trondheimsleia & 63.60601667 & 9.41488333 & 150 & ROV \\
28 March 2010 & 2010001 & Glossvika, Gulen & 60.9574667 & 5.1298667 & $1-30$ & SCUBA \\
10 Jul 2010 & 2010006 & Stanggapet, Kragerø & 58.81985 & 9.48798333 & $15-25$ & SCUBA \\
17 Jul 2010 & 2010007 & Bamle, Telemark & 58.9615 & 9.679 & 10 & SCUBA \\
25 Aug 2010 & 2010009 & Trondheim Biological Station, & 63.4408333 & 10.348889 & $5-20$ & SCUBA \\
26 March 2011 & 2011005 & Grondheim & 60.9574667 & 5.1298667 & $1-30$ & SCUBA \\
26 March 2011 & 2011006 & Øskjeneset, Gulen & 60.9706 & 5.18037 & $20-30$ & SCUBA \\
28 March 2011 & 2011008 & Svalnestangen, Trondheimsfjord & 63.3310645 & 10.1013206 & 30 & SCUBA \\
26 May 2011 & 2011012 & Ærøydypet, Arendal & & & $90-100$ & RP-dredge \\
11 June 2011 & 2011026 & Glossvika, Gulen & 60.9574667 & 5.1298667 & $1-30$ & SCUBA \\
23 March 2012 & 2012001 & Glossvika, Gulen & 60.9574667 & 5.1298667 & $1-30$ & SCUBA \\
10 March 2012 & 2012002 & Ormøy, Stavanger & 58.98617 & 5.76222 & $20-40$ & SCUBA \\
21 Oct 2007 & R189-349 & Bleiksdjupet, Andøya & 69.3762 & 15,7306 & $881-907$ & Beam trawl \\
5 Oct 2007 & R108-335 & Malangsgrunnen & 70.1183 & 17.1138 & $503-493$ & Beam trawl \\
\hline
\end{tabular}


specimens in good condition were found, measuring 11 and $7 \mathrm{~mm}$ respectively. The largest specimen recorded is $12 \mathrm{~mm}$ long (Bergh 1899). Photos of the MAREANO specimens can be found on the MAREANO web page (http://www.mareano. no/nyheter/nyheter_2008/nakensnegl).

\section{Goniodoris castanea (Alder \& Hancock, 1845)}

Figure 1A

Goniodoris castanea.- Alder \& Hancock 1847: part III, fam.

1, pl. 19, fig. 1-10.- Thompson \& Brown 1984: 40, pl. 10a-c, pl. 13b, fig. 7c.

Material examined: NTNU-VM 67041 (1), stn 2011005.

Remarks: According to Thompson \& Brown (1984) this species has a worldwide distribution but is not commonly found in any individual locality; the southern coast of Norway was given as the northern limit of distribution. We have so far not been able to find any previous records from Norwegian waters to corroborate this. Our observation therefore seems to be the first confirmed record of this species from Norwegian waters. The relatively large specimen, $20 \mathrm{~mm}$ body length, was found on kelp (Laminaria hyperborea) at Gulen at $5 \mathrm{~m}$ depth.

\section{Lophodoris danielsseni (Friele \& Hansen, 1876)}

Goniodoris danielsseni Friele \& Hansen 1876: 72.

Lophodoris danielsseni G.O. Sars 1878: tab. XIV, fig. 7.Odhner 1922: 25, fig. 9.- Just \& Edmunds 1985:62, pl. 27AE.- Evertsen \& Bakken 2005: 9.

Material examined: NTNU-VM 67252 (1), stn 2007007; NTNU-VM 66888 (1), stn 2010001; NTNU-VM 66889 (1), stn 2010001; NTNU-VM 66890 (1), stn 2010001; NTNUVM 67031-67033 (2), stn 2010001; NTNU-VM 67033 (1), stn 2010009; NTNU-VM 67034 (1), stn 2011006; NTNU-VM 67035-67036 (2), stn 2011008.

Remarks: The original description was based on specimens from Florø (Friele \& Hansen 1876), not far from the locality at Gulen, and it was considered among the rarest sea slugs in Norwegian waters due to few records spanning from Hordaland to Trøndelag (Evertsen \& Bakken 2005). It is therefore interesting to see that it has been present in large numbers at Gulen from 2010 onwards, and it has also been found it in the Trondheimsfjord in the same period. Even though we do not extend its known distribution, its presence in large numbers suggests that this species will occur elsewhere along the Norwegian coast.

\section{Onchidoris depressa Alder \& Hancock, 1842}

Onchidoris depressa.- Alder \& Hancock 1851: part V, fam. X, pl. x.- Just \& Edmunds 1985: 68, pl. 30A-F.- Evertsen \& Bakken 2005: 11.
Material examined: NTNU-VM 62638 (1), stn 2008003; NTNU-VM 66103 (1), stn 2011005.

Remarks: Previously only known from one sample collected by Carl Dons from Røberg in the Trondheimsfjord (Evertsen \& Bakken 2005), the two new records of this species reported here is the second and third record from Norwegian waters, from Mausund and Gulen respectively. This extends the distribution from Trøndelag to Sogn og Fjordane. According to Thompson \& Brown (1984) this species is easily overlooked as it is well hidden among encrusting bryozoans. This may explain its few records not only in Norway, but also in its entire distribution range which spans south to the Mediterranean Sea.

\section{Onchidoris sparsa (Alder \& Hancock, 1846)}

\section{Figure 1D}

Onchidoris sparsa.- Alder \& Hancock 1848: part IV, fam. 1, pl. 14, figs 1-7.- Thompson \& Brown 1984: 62, fig. 9e., pl. $15 \mathrm{~h}, \mathrm{I}$.

Material examined: NTNU-VM 62620 (1), stn 2008004.

Remarks: The distribution of this rare species with few observations ranges from the Atlantic coast of Spain north to the west coast of Sweden (Thompson \& Brown 1984), and was mentioned from Norway by Høisæter (1986) with reference to Just \& Edmunds (1985). There were, however, no primary records confirming its presence in Norwegian waters (Evertsen \& Bakken 2005). Our record from Frøya in 2008 therefore finally confirms that this species occurs in Norwegian waters. One specimen measuring $8 \mathrm{~mm}$ in length was found in the kelp forest at Bukkholman, Mausund. This is a small species of Onchidoris which can be difficult to distinguish from similar species like Onchidoris inconspicua and Onchidoris depressa (Picton \& Morrow 1994), which may explain why it is so rarely observed.

\section{Palio nothus Johnston, 1838}

Polycera ocellata Friele \& Hansen 1876: 73.- G.O. Sars 1878: tab. XIV.

Palio ocellata Odhner.- 1907: 70.

Thecacera virescens.- G.O. Sars 1878: tab. XIV, fig. 17.Odhner 1907: 70.- 1939: 37.- Grieg 1914: 91.

Palio nothus.- Alder \& Hancock 1846: part II, fam. 1, pl. 23, figs 1-11.- Thompson \& Brown 1984:74, fig. 14c, pl. 20a-c.Evertsen \& Bakken 2005: 16-17.

Material examined: NTNU-VM 66830 (1), stn 2010001

Remarks: According to Thompson \& Brown (1984) this species has an amphi-Atlantic and boreo-arctic distribution, but they were concerned with the true identity in many of these observations since Palio nothus is easily confused with Palio dubia. This was also duly noted in Evertsen \& Bakken (2005) where previous records from Norwegian waters were corrected. 
Our present observation is therefore only the third record of this species in Norway, now found at Gulen, not far from where Friele \& Hansen (1876) first recorded this species from Norwegian waters. Our extensive sampling the last few years has only revealed $P$. dubia, which indicates that $P$. nothus is a rare species.

\section{Tritonia griegi Odhner, 1922}

Tritonia griegi Odhner 1922: 6, fig. 1.- 1939: 44.- Evertsen \& Bakken 2005: 20.

Tritonia hombergi.- Storm 1879: 17.

Tritonia (Candiella) plebeia var.- Grieg 1897: 27.

Duvaucelia (Tritonidoxa) griegi.- Odhner 1926: 15, fig. 9-11.

Material examined: NTNU-VM 66063 (1), stn 2009012; NTNU-VM 67019 (1), stn 2009024.

Remarks: This species was originally described by Odhner in 1922 based on specimens collected by James A. Grieg from Skjærjehamn at Gulen in 1897-1898, then identified as Tritonia plebeia. What makes this species interesting is that it has only been found from deeper waters (70 to 400 meters depth) from dredging hauls often conducted in coral rich localities. It is mainly known from Norwegian waters with an exceptional observation from the Bay of Biscay (Bouchet 1977). This species has only been found as single records, and is considered rare (Evertsen \& Bakken 2005). The new records from Agdenes in the Trondheimsfjord presented here confirm this, as they also represent single records in similar habitats and localities from where it was previously known (Odhner 1926, 1939).

\section{Tritonia lineata Alder \& Hancock, 1848}

Tritonia lineata.- G.O. Sars 1878: 364, 377.- Evertsen \& Bakken 2005: 21.

Material examined: NTNU-VM 66952 (1), stn 2011005; NTNU-VM 67951-67953 (6), stn 2012002; NTNU-VM 67953 (4), stn 2012002; NTNU-VM 68111 (1), Hestøy, Hitra, 16 June 2012, 40 m, SCUBA, coll. Torjus Haukvik.

Remarks: Until now, this species was only known from Norway from a single record from Florø by G.O Sars (1878). It is not uncommon from the Mediterranean Sea north to the British Isles (Thompson \& Brown 1984), but has so far not been observed in Norwegian waters after the find by G.O Sars. This species has now been observed from Stavanger, Gulen and Hitra. It has also been documented from photographs taken in the Trondheimsfjord in 2006 (Kåre Telnes pers. comm. - www.seawater.no), extending it distribution from Rogaland to Trøndelag.

\section{Hero formosa (Lovén, 1841)}

Clöelia trilineata M. Sars 1851: 194.
Hero formosa.- M. Sars 1870: 193.- G.O. Sars 1878: 316, tab. 28, fig. 3a-d, tab. XV, fig. 5a-c.- Grieg 1897: 22, 31.1932:15.- Friele \& Grieg 1901: 120.- Odhner 1907: 88.- 1922: 34.- Larsen 1925: 42.- Evertsen \& Bakken 2005: 22.

Material examined: NTNU-VM 67013 (1), stn 2010001; NTNU-VM 67012 (1), stn 2011005; NTNU-VM 67014 (1); NTNU-VM 67121 (1), stn 2011012; NTNU-VM 67945 (1), Svalnestangen, Trondheimsfjord, 20 May 2012, 27 m, SCUBA, coll. Sigbjørn H. Vorren.

Remarks: Hero formosa has a wide distribution along the coast of Norway from the Oslofjord north to Troms (Evertsen \& Bakken 2005), but is so far only known from deeper waters down to $270 \mathrm{~m}$ depth from dredging. Our recent observations of this species suggest that it is also common in waters shallower than 30 meters and that it also can be quite common at single localities as it has been found repeatedly at Gulen since 2009.

\section{Janolus cristatus (delle Chiaje, 1841)}

Janolus cristatus.- G.O Sars 1878: annotations.- Moen \& Svensen 2008: 422-423.- Evertsen \& Bakken 2005: 22.

Material examined: NTNU-VM 67020 (1), stn 2010006.

Remarks: This elusive species has previously only been found from Rogaland (Evertsen \& Bakken 2005; Moen \& Svensen 2008). It has a more southern distribution from the Mediterranean Sea to the British Isles (Thompson \& Brown 1984). Our single observation of this species at Gulen extends its known distribution to Sogn og Fjordane, but it also confirms its rarity along the coast of Norway.

\section{Eubranchus rupium (Möller, 1842)}

Figure 1B

Tergipes rupium Möller 1842: 78.

Eubranchus rupium.- Bergh 1864: 220, tab. III, figs 1-18.Lemche 1935: 144, fig. 8a.- Just \& Edmunds 1985: 110, pl. $51 \mathrm{~A}-\mathrm{G}$.

Material examined: NTNU-VM 66954 (1), stn 2010001; NTNU-VM 67107-67108 (2, 10-15 mm in length), stn 2010001; NTNU-VM 67134-67137 (7), stn 2010001; NTNU-VM 65367 (1), $\operatorname{stn} 2009009$.

Remarks: This species was originally described from Greenland as Tergipes rupium (Möller 1842). There has been some confusion as to this species' distribution as Möller thought it was identical to Tergipes tergipes. This mistake was rectified by Bergh (1864). Lemche $(1935,1941)$ aired some suspicion that this species is the same as Eubranchus pallidus, but our specimens fit the descriptions of E. rupium and it is considerably different from E. pallidus. Our observations of this species from Gulen and the Trondheimsfjord are the first confirmed records of this species along the coast of Norway. Its rarity can 
be attributed to the fact that this species can easily be confused with other species of Eubranchus and that it is poorly known in the literature.

\section{Cumanotus beaumonti (Eliot, 1906)}

Cumanotus laticeps.- Odhner 1907:80.

Cumanotus beaumonti.- Evertsen \& Bakken 2002: 18.- 2005: 23-24.

Material examined: NTNU-VM 67118-67119 (2), stn 2011026. Remarks: This species was previously only known from two single records from Nordland and Finnmark (Evertsen \& Bakken 2002; 2005). The present record from Gulen extends its distribution south to Sogn og Fjordane, where it has been found frequently at the same locality in March/April when its prey, the hydroid Corymorpha nutans, is present, (Christian Skauge pers. obs.).

\section{Berghia norvegica Odhner, 1939}

Berghia norvegica Odhner, 1939: 85, figs 52-59.- Evertsen \& Bakken 2005: 31.

Material examined: NTNU-VM 66967 (1), stn 2011005;
NTNU-VM 67955-67961 (7, 20-30 mm in length), stn 2012001. Remarks: This species was only known from the original description by two records from off the Trondheimsfjord (Storhallaren, Frøya and Stjørna in the mouth of the Trondheimsfjord) where it was found by Odhner in 1939. Since then it has been forgotten and not been looked for until it was rediscovered in 2011 and again found in great numbers in 2012 at Gulen. Even though it belongs to the aeolidacean family it has little resemblance with the other known species from Norway and has previously probably been misidentified with more similar looking species within the cuthonid family. We also only found it sheltering beneath rubble and dead shells, which makes it very difficult to find unless you are actively searching for it in these habitats. Our observations extend its distribution from Trøndelag to Sogn og Fjordane.

\section{Calma glaucoides Alder \& Hancock, 1852}

Eolis albicans.- Friele \& Hansen 1876: 78, tab. 2, fig. XIV. Calma glaucoides.- Odhner 1939: 76.- Dons 1942c: 194.Evertsen \& Bakken 2005: 31.

Material examined: NTNU-VM 66988 (1), stn 2010007.

Remarks: The present record is only the third confirmed record from Norwegian waters (Evertsen \& Bakken 2005). It may

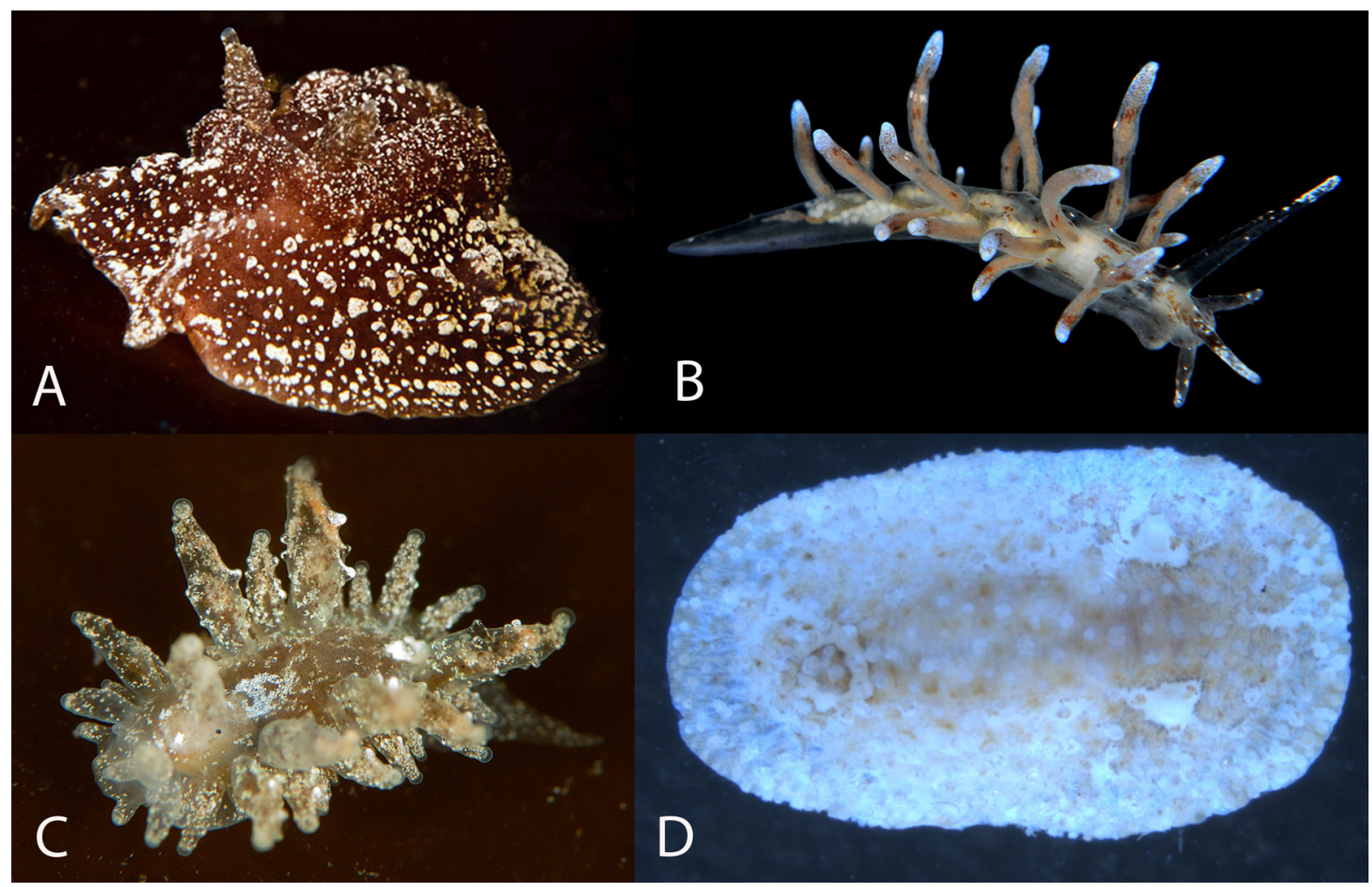

Figure 1. Live and lab images of species reported new to Norway. Information on size is given in the text for each species. A, Goniodoris castanea, in situ photograph from Gulen in 2011 (NTNU-VM 67041). B, Eubranchus rupium, in situ photograph from Gulen in 2010. C, Proctonotus mucroniferus, in situ photograph from Bergen in 2009. D, Onchidoris sparsa, lab photograph of recently fixed specimen from Mausund in 2008 (NTNU-VM 62620). Photos: A Thorbjørn Rusnes; B and C Christian Skauge; D Torkild Bakken. 
resemble other aeolid species and may be difficult to identify and observe in situ. Due to this it may have been overlooked.

\section{Proctonous mucroniferus (Alder \& Hancock, 1844)}

\section{Figure 1C}

Proctonotus mucroniferus Alder \& Hancock 1844: 163.Thompson \& Brown 1984: 100, fig. 24.

\section{Material examined: Only studied in field.}

Remarks: This species is quite rare since it has very few records exclusively from the British Isles since its description in 1844 (Thompson \& Brown 1984). We found one specimen at Gulen in 2010, but it was unfortunately not preserved. More specimens have been observed several times from the Bergen region, and documented in situ by photographs, by Bjørnar Nygård and Cristian Skauge (identified by the authors from photographs). This is the first record of this species outside the British Isles, and in Norway.

\section{DISCUSSION}

Documenting 5 new species to coastal waters brings the nudibranch fauna in Norwegian coastal waters to a total of 87 species (Appendix 1). Several of the species reported here have been regarded as rare in the sense that they have very few records in Norwegian waters the last 250 years (Evertsen \& Bakken 2005). However, with SCUBA-diving and the help of many eyes focused on spotting nudibranchs, many of these rare species can be regarded as more or less common in some of the localities where divers have learnt to look for them. Species have been recorded from the same localities over 3-4 years, and for some species the distribution range has been enlarged. The rarity of many of the nudibranchs do not seem to adhere to the definition of small populations along the coast of Norway, but more to the fact that no-one has been looking for them, or been able to observe them.

Increased knowledge on distribution and abundance is important for knowledge on diversity in general. Nudibranchs have been included in assessments for the Norwegian Red List with a result that $28 \%$ of the species were redlisted, but all included species were assessed to the data deficient (DD) category (Sneli et al. 2010). Documentation of new records and increased knowledge contribute to better understanding of diversity and to better foundations for assessments of rarity, red list categories and invasions.

New records from Norway and increased observations and records of species compared to previously known distributions have in some instances been advocated to climate change and increased sea water temperatures. A recent report on changes in macrobenthic organisms discuss different scenarios for changes, among them increase in sea temperature (Brattegard 2010). The primary conclusion from the present study on nudi- branchs is that increased effort and sampling intensity coupled with skills result in increased knowledge at given localities.

\section{ACKNOWLEDGMENTS}

We are grateful to all who have contributed in sampling specimens: Christian Skauge, Thorbjørn Rusnes, Bjørnar Nygård, Torjus Haukvik, Rudolf Svensen, Sigbjørn Hjetland Vorren, to participants in the "Nudibranch Safari" at Gulen 2010-2012, and to Halldis Ringvold MAREANO for sending specimens of Doridoxa ingolfiana for us to study. We are especially grateful to Monica Bakkeli and Ørjan Sandnes at Gulen Diving Resort, as well as to Christian Skauge for their hospitality, encouragement and enthusiasm. Christian Skauge and Thorbjørn Rusnes are thanked for letting us use their images.

\section{REFERENCES}

Alder J, Hancock A. 1844. Description of a new genus of nudibranchiate Mollusca, with some new species of Eolis. Annals \& Magazine of Natural History 13(83):161-167, pl. 2.

Alder J, Hancock A. 1846. A monograph of the British nudibranchiate Mollusca: with figures of all the species. Part II. Ray Society, London.

Alder J, Hancock A. 1847. A monograph of the British nudibranchiate Mollusca: with figures of all the species. Part III. Ray Society, London.

Alder J, Hancock A. 1848. A monograph of the British nudibranchiate Mollusca: with figures of all the species. Part IV. Ray Society, London.

Alder J, Hancock A. 1851. A monograph of the British nudibranchiate Mollusca: with figures of all the species. Part V. Ray Society, London.

Brattegard T. 2010. Endringer i norsk marin bunnfauna 1997 - 2010. Utredning for DN 2011-8. Direktoratet for naturforvaltning.

Bergh LSR. 1864. Anatomiske Bidrag til kundskab om aeolidierne. Det Kongelige Danske videnskabernes selskabs skrifter, Naturvidenskab og Mathematisk Række 7: 139-316.

Bergh LSR. 1899. Nudibranches et Marsenia provenant des campagnes de la Princesse-Alice, (1891-97). Resultats des Campagnes Scientifiques accomplies sur son yacht (Hirondelle) par Albert Ier prince souverain de Monaco 14: 1-46.

Bergh LSR. 1900. Nudibranchiate Gasteropoda. The Danish Ingolf-Expedition 2(3): 1-49.

Bouchet P. 1977. Opisthobranches de profondeur de l'ocean atlantique: II. Notaspidea et Nudibranchiata. Journal of Molluscan Studies 43(1):28-66.

Evertsen J, Bakken T. 2002. Heterobranchia (Mollusca, Gastropoda) from northern Norway, with notes on ecology and distribution. Fauna norvegica 22: 15-22.

Evertsen J, Bakken T. 2005. Nudibranch diversity (Heterobranchia, Gastropoda) along the coast of Norway. Fauna norvegica 25: 1-37.

Friele H, Hansen A. 1876. Bidrag til Kundskaben om de nor- 
ske Nudibranchier. Forhandlinger i Videnskabs-Selskabet i Christiania 1875: 69-80.

Grieg JA. 1897. Bidrag til Kundskaben om Vestlandets mollusker. Bergens Museums Aarbog 1896: 1-32.

Grieg JA. 1914. Bidrag til kundskapen om Hardangerfjordens fauna. Bergens Museums Aarbok, 1913: 1-147.

Høisæter T. 1986. An annotated check-list of marine molluscs of the Norwegian coast and adjacent waters. Sarsia 71(2): 73-175.

Just H, Edmunds M. 1985. North Atlantic nudibranchs (Mollusca) seen by Henning Lemche, with additional species from the Mediterranean and the northeast Pacific. Ophelia supplement 2: $1-170$.

Larsen M. 1925. Nudibranchfaunaen i Drøbaksundet. II: Holoog cladohepatica. Videnskapsselskapets Skrifter MathematiskNaturvitenskabelig Klasse 1925: 1-60.

Lemche HM. 1935. On some nudibranchiate gastropods from the Northern Atlantic. Videnskabelige Meddelelser Dansk naturhistorisk Forenening 99: 131-148.

Lemche HM. 1941. The zoology of east Greenland. Gastropoda Opisthobranchiata. Meddelelser om Grønland, 121(7): 1-50.

Moen FE, Svensen E. 2008. Dyreliv i havet: nordeuropeisk marin fauna. KOM forlag.

Möller HPC. 1842. Index Molluscorum Groenlandiae. C. A Reitzelii, Hafniae.

Odhner NH. 1907. Northern and Arctic invertebrates in the collection of the Swedish State Museum. III. Opisthobranchia and Pteropoda. Kungliga Svenska Vetenskapsakademiens Handlingar 41: 1-118.

Odhner NH. 1922. Norwegian ophistobranchiate Mollusca in the collections of the Zoological museum of Kristiania. Nyt Magazin for Naturvidenskaberne 60: 1-47.

Odhner NH. 1926. Nudibranchs and lamellariids from the Trondhjem fjord. Det Kongelige Norske Videnskabers Selskabs Skrifter 2: 1-36.

Odhner NH. 1939. Ophistiobranchiate Mollusca from the western and northern coasts of Norway. Det Kongelige Norske Videnskabers Selskabs Skrifter 1: 1-92.

Picton BE, Morrow CC. 1994. A field guide to the nudibranchs of the British Isles. Immel Publishing.

Sars GO. 1878. Bidrag til Kunskaben on Norges arktiske Fauna. I. Mollusca Regionis Arcticæ Norvegiæ. Oversigt over de i Norges arktiske Region forekommende Bløddyr. Universitetsprogram for første halvaar 1878, Christiania: Brøgger, s. 1-466.

Sars M. 1851. Beretning om en i Sommeren 1849 foretagen zoologisk Reise i Lofoten og Finmarken. Nyt Magazin for Naturvidenskaberne 6: 121-211.

Sars M. 1870. Bidrag til Kundskab om Christianiafjordens Fauna. II. Nyt Magazin for Naturvidenskaberne 17: 113-232.

Sneli J-A, Schiøtte T, Jensen KR, Wikander PB, Stokland Ø. 2005. The Marine Mollusca of the Faroes. Supplementum 42, Føroya Fróðskaparfelag.

Sneli J-A, Evertsen J, Johannessen J, Olsen KM, Schander C, Stokland Ø, Wikander PB. 2010. Bløtdyr - Mollusca. Pages 371-385 in Kålås JA, Viken Å, Henriksen S, Skjelseth S, eds. The Norwegian Red List for species. Norwegian Biodiversity Information Centre, Norway.

Storm, V. 1879. Bidrag til Kundskab om Throndhjemsfjordens Fauna. Det Kongelige Norske Videnskabers Selskabs Skrifter 1878: 9-36.
Thompson TE, Brown GH. 1984. Biology of opisthobranch molluscs, vol. 2 no. 156. Ray Society. London.

Editorial responsibility: Åslaug Viken.

This article is open-access and distributed under the terms of the Creative Commons Attribution-Noncommercial 3.0 Unported License (http://creativecommons.org/licenses/by-nc/3.0/). This permits all non-commercial use, distribution, and reproduction in any medium, provided the original work is properly cited.

Appendix 1. A total account of the 87 species of Nudibranchia known from Norwegian waters.

\section{Nudipleura Wägele \& Willan, 2000 \\ Nudibranchia Ducrotay-Blainville, 1814 sensu Odhner 1934}

Anthobranchia Minichev, 1970 sensu Baranetz \& Minichev 1995

Doridoidea Rafinesque, 1815 sensu Wägele 1989

Doridoxidae Bergh, 1899

Doridoxa ingolfiana Bergh, 1899 new record

Aegiretidae P. Fischer, 1883

Aegires punctilucens (d'Orbigny, 1837)

Triopella incisa (M. Sars in G. O. Sars, 1872)

Goniodorididae H. \& A. Adams, 1854

Ancula gibbosa (Risso, 1818)

Goniodoris nodosa (Montagu, 1818)

Goniodoris castanea Alder \& Hancock, 1845 new record

Lophodoris danielsseni (Friele \& Hansen, 1876)

Okenia pulchella (Alder \& Hancock, 1854)

Onchidorididae J. E. Gray, 1827

Acanthodoris pilosa (Abildgard, 1789)

Adalaria loveni (Alder \& Hancock, 1862)

Adalaria proxima (Alder \& Hancock, 1854)

Doridunculus echinulatus G. O. Sars, 1878

Onchidoris bilamellata (Linnaeus, 1767)

Onchidoris depressa (Alder \& Hancock, 1842)

Onchidoris inconspicua (Alder \& Hancock, 1851)

Onchidoris muricata (Müller, 1776)

Onchidoris pusilla (Alder \& Hancock, 1845)

Onchidoris sparsa (Alder \& Hancock, 1846) new record

Diaphorodoris luteocincta (M. Sars, 1870)

Dorididae Rafinesque, 1815

Doris nobilis Lovén in Odhner, 1907

Doris pseudoargus (Rapp, 1827)

Aldisa zetlandica (Alder \& Hancock, 1854)

Chromodorididae Bergh, 1891

Cadlina glabra (Friele \& Hansen, 1876)

Cadlina laevis (Linnaeus, 1767)

Discodorididae Bergh, 1891

Geitodoris planata (Alder \& Hancock, 1846)

Jorunna tomentosa (Cuvier, 1804)

Rostanga setidens (Odhner, 1939)

Continued on next page. 
Appendix 1. Continued.

Rostanga rubra (Risso, 1818)

Polyceridae Alder \& Hancock, 1845

Issena pacifica (Bergh, 1894)

Limacia clavigera (Müller, 1776)

Palio dubia (M. Sars, 1829)

Palio nothus (Johnston, 1838)

Polycera faeroensis Lemche, 1929

Polycera quadrilineata (Müller, 1776)

Cladobranchia Willan \& Morton, 1984

Dendronotoidea N. H. Odhner 1934

Dendronotidae J. E. Gray, 1857 sensu Odhner 1936

Dendronotus frondosus (Ascanius, 1770)

Dendronotus robustus Verrill, 1870

Dotidae J. E Gray, 1853

Doto coronata (Gmelin, 1791)

Doto crassicornis (M. Sars, 1870)

Doto cuspidata Alder \& Hancock, 1862

Doto fragilis (Forbes, 1838)

Doto koenneckeri Lemche, 1976

Tritoniidae de Lamarck, 1809

Tritonia griegi Odhner, 1922

Tritonia hombergi Cuvier, 1803

Tritonia lineata Alder \& Hancock, 1848

Tritonia plebiea Johnston, 1828

“Arminoidea" Rafinesque, 1814 sensu Odhner 1934

Arminidae Rafinesque, 1814

Armina loveni (Bergh, 1860)

Heterodorididae Verrill \& Emerton, 1882

Heterodoris robusta Verrill \& Emerton, 1882

Heroidae Bergh, 1892

Hero formosa (Lovén, 1841)

Zephyrinidae Iredale \& O'Donoghue, 1923

Janolus cristatus (delle Chiaje, 1841)

Proctonotus mucroniferus (Alder \& Hancock, 1844) new record

Goniaeolididae Odhner, 1907

Goniaeolis typica M. Sars, 1861

Aeolidoidea Odhner, 1934

Eubranchidae Odhner, 1934

Eubranchus exiguus (Alder \& Hancock, 1848)

Eubranchus farrani (Alder \& Hancock, 1844)

Eubranchus pallidus (Alder \& Hancock, 1842)

Eubranchus rupium (Møller, 1842) new record

Eubrancus tricolor Forbes, 1838

Eubranchus vittatus (Alder \& Hancock, 1842)

Cumanotidae Odhner, 1907

Cumanotus beaumonti (Eliot, 1906)

Embletoniidae Pruvot-Fol, 1954

Embletonia pulchra Alder \& Hancock, 1851

Tergipedidae Bergh, 1899

Cuthona caerulea (Montagu, 1804)

Cuthona concinna (Alder \& Hancock, 1843)
Cuthona distans (Odhner, 1922)

Cuthona foliata (Forbes \& Goodsir, 1839)

Cuthona gymnota (Couthoy, 1838)

Cuthona nana (Alder \& Hancock, 1842)

Cuthona norvegica (Odhner, 1929)

Cuthona pustulata (Alder \& Hancock, 1854)

Cuthona rubescens Picton \& Brown, 1978

Cuthona viridis (Forbes, 1840)

Tergipes tergipes (Forskål, 1775)

Tenellia adspersa (Nordmann, 1845)

Flabellinidae Bergh, 1889

Flabellina borealis (Odhner, 1922)

Flabellina gracilis (Alder \& Hancock, 1844)

Flabellina lineata (Lovén, 1846)

Flabellina nobilis Verrill, 1880

Flabellina pedata (Montagu, 1815)

Flabellina pellucida (Alder \& Hancock, 1843)

Flabellina salmonacea (Couthouy, 1838)

Flabellina verrucosa (M. Sars, 1829)

Aeolididae d'Orbigny, 1834

Aeolidia papillosa (Linnaeus, 1761)

Aeolidiella glauca (Alder \& Hancock, 1845)

Berghia norvegica Odhner, 1939

Calmidae Iredale \& O'Donoghue, 1923

Calma glaucoides Alder \& Hancock, 1855

Facelinidae Bergh, 1889

Facelina bostoniensis (Couthouy, 1838)

Facelina auriculata (Müller, 1776 non Odhner 1939)

Favorinidae Bergh, 1889

Favorinus blianus Lemche \& Thompson, 1974

Favorinus branchialis (Rathke, 1806) 